\title{
Byssoloma subdiscordans (Nyl.) P. J ames: Distributional range and its habitat preference in Indian subcontinent
}

\author{
Y.J oshi* and M. Tripathi \\ Lichenology Division, Department of Botany, S.S.J. Campus, Kumaun University, Almora-263601 (Uttarakhand), INDIA \\ ${ }^{*}$ Corresponding author. E-mail: dryogeshcalo@gmail.com
}

Received:J uly 10, 2013; Revised received: August 14, 2013; Accepted: August 25, 2013

\begin{abstract}
The present paper deals with the new distributional record of Byssoloma subdiscordans for Western Himalayan lichen flora and a new habitat record for Indian subcontinent. A note on its brief taxonomic description, distribution, ecology and occurrence in India is also provided. Previously the species was reported as corticolous and foliicolous from tropical and montane regions of India, viz. Eastern Himalaya and Western Ghats, but this is for the first time that authors have reported it as saxicolous in temperate regions of Western Himalaya, thus extending its habitat preference along with distributional range within Indian subcontinent.
\end{abstract}

Keywords: Byssoloma, Foliicolous, Indian subcontinent, Kumaun Himalaya, Lichenized fungi, New record, Saxicolous

\section{INTRODUCTION}

The lichens of India have been nicely investigated and compiled by Singh and Sinha (2010) in their checklist "Indian Lichens: An Annotated Checklist", which includes 2303 species belonging to 305 genera and 74 families from tropical, subtropical, temperate and alpine regions colonizing various substrates.

Uttarakhand, one of the culturally rich heritage state of India, is also home to a diverse assemblage of lichens (Upreti et al., 2010), and since last four decades, lichenological studies within this region have yielded a noteworthy increase in lichen taxa which is partly due to local floristic investigations and revisionary studies of certain families or genera (e.g. Awasthi, 1975; 1986; Pant, 2002; Nayaka, 2004; Divakar and Upreti, 2005; Gauniyal, 2005; Joshi, 2008; Joshi, 2010; Mishra, 2012; Upreti and Chatterjee, 1999; 2000; Upreti et al., 2001; 2010). The state is bestowed with 747 species of lichens (Rai 2013).

During a field trip to Jageshwar, a small village amidst the dense grove of the funereal deodar [Cedrus deodara (Roxb.) G. Don] trees that even sunrays find hard to penetrate for most part of the year, situated at an altitude of $1870 \mathrm{~m}, 37 \mathrm{~km}$ north east of Almora on main road to Pithoragarh, the authors found luxuriant growth of lichenized fungi, such as, Buellia De Not., Caloplaca flavovirescens (Wulfen) Dalla Torre and Sarnth., C. subsoluta (Nyl.) Zahlbr., Candelariella Müll. Arg., Heterodermia pseudospeciosa (Kurok.) W.L. Culb., $\mathrm{H}$ yperphyscia adglutinata (Flörke), H. Mayrhofer and Poelt, Lecanora luteomarginata Nayaka, Upreti and Lumbsch, Lepraria sp. Ach., Mycobilimbia philippina
(Vain.) D.D. Awasthi, Pertusaria DC., Porpidia albocoerules (Wulfen) Hertel \& Knoph, Punctelia rudecta (Ach.) Krog, Ramalina hossei Vain. and Tephromela khatiensis (Räsänen) Lumbsch, besides a saxicolous Byssoloma Trevis. in and around rocks of the monuments.

Byssoloma a cosmopolitan genus of lichenized fungi, belonging to family Pilocarpaceae is represented by ca. 55 species worldwide (Kirk et al., 2008). Generally it is foliicolous lichen but two of its species [B. leucoblepharum (Nyl.) Vain. and B. subdiscordans (Nyl.) P. James] colonizes various substrates such as rock and bark (Lücking, 2008). Altogether 5 taxa have been recognized and accepted from Indian subcontinent viz. B. chlorinum (Vain.) Zahlbr., B. leucoblepharum, B. polychromum (Müll. Arg.) Zahlbr., B subdiscordans and B. tricholomum (Mont.) Zahlbr. (Singh and Sinha, 2010). The aim of present study was to study the distributional range and habitat preference of Byssoloma subdiscordans (Nyl.) in Indian subcontinent.

The saxicolous Byssoloma species on its examination revealed to be $B$. subdiscordans. Brief taxonomic description of the species is provided herewith.

\section{MATERIALS AND METHODS}

The present study is based on lichen specimens of Byssoloma species collected from Jageshwar forest, Almora district, Uttarakhand and deposited at herbarium of Kumaun University (ALM), Uttarakhand, India. Morphological characters of thallus, reproductive structures, colour, size and shapes were examined under stereozoom dissecting microscope. Hand-cut sections 



Fig. 1. A. Habitat of B. subdiscordans (Encircled area showing the target species) (Scale $=5 \mathrm{~mm}$ ). B. Magnified view of $B$. subdiscordans $($ Scale $=1 \mathrm{~mm})$.

were made for studying the anatomy of thalli and fruiting bodies and were examined under compound microscope. Spot test reactions were carried out on hand sections of thalli and apothecia under compound microscope. Thin layer chromatography (TLC) was performed as described by Orange et al. (2001).

\section{RESULTS}

\section{Taxonomic treatment}

Byssoloma subdiscordans (Nyl.) P. James, Lichenologist 5: 126, 1971. (Fig. 1A-B)

Thallus dispersed into rounded to confluent patches, 1 $\mathrm{cm}$ across, with corticiform layer, smooth, whitish. Apothecia round, 0.3-0.4 mm diam., disc plane to slightly convex, black; margin well developed and byssoid, spreading laterally over thallus surface, white. Exciple well developed, hyaline, of loosely woven hyphae. Hypothecium 20-35 $\mu \mathrm{m}$ high, dark brown with purple tinge. Epithecium well developed, 6-7 $\mu \mathrm{m}$ high, blackish brown with purple tinge. Hymenium 50-55 $\mu \mathrm{m}$ high, hyaline. Asci 40-45 $\times 9-10 \mu \mathrm{m}$. Ascospores oblongellipsoid, 3-septate, 11-14 ×3 $\mu \mathrm{m}$. Pycnidia not seen.

Chemistry: no lichen substances present.

Specimen examined: India, Uttarakhand, Almora district, Jageshwar, 29ú37'44.5" N 0.79ú50’20.3" E, 1828 m, on granite rock, 26 Oct. 2012, H. Joshi \& party, 0051 (ALM).

\section{DISCUSSION}

B. subdiscordans is reported on leaves, bark and rock in tropical, temperate and arctic regions across the world (Lücking, 2008; Giavarini and Sérusiaux, 2009). It is generally a pantropical species (Santesson, 1952; Lücking, 1992; 2008), but is also reported from temperate regions of Australia, Europe, Japan, New Zealand, North America, Taiwan (Santesson, 1952; Kantvilas and Jarman, 1993; Wirth, 1995; Aptroot, 1996; Thor et al., 2000; Aptroot and Sparrius, 2003; Hermansson and Thor, 2004;
Lücking, 2008; Giavarini and Sérusiaux, 2009) growing on bark, leaves and rocks.

Previous reports of B subdiscordans in India show a restricted distribution of this species in subtropical and montane regions of Eastern Himalaya (Arunachal Pradesh, Manipur, Nagaland, Sikkim) (Pinokiyo and Singh, 2004; Pinokiyo et al., 2006; Sinha and Jagadeesh Ram, 2011) and Western Ghats (Tamil Nadu) (Awasthi and Singh, 1972; Awasthi, 1991; Pinokiyo et al., 2006) growing over bark and leaves. In the present study, the species is recorded for the first time from Western Himalaya growing in deep shady areas on vertical surface of granitiferous biotite granite gneiss (a metamorphic rock) of Almora Crystalline Group of Gumalikhet Formation in the locality of Jageshwar. A single colony of this lichen was obtained and investigated from the study area. At the collecting site, the species was accompanied by various lichens [e.g. Buellia sp., Caloplaca flavovirescens (Wulfen) Dalla Torre \& Sarnth., C. subsoluta (Nyl.) Zahlbr., Lecanora luteomarginata Nayaka, Upreti and Lumbsch, Lepraria sp., Mycobilimbia philippina (Vain.) D.D. Awasthi, Pertusaria DC., Porpidia albocoerulesce (Wulfen) Hertel and Knoph and Tephromela khatiensis (Räsänen) Lumbsch].

It is quite surprising that similar set of conditions, such as damp and shady areas have been mentioned for saxicolous specimens for this species in Europe by Giavarini and Sérusiaux (2009). However, the saxicolous specimens of this species from Taiwan were reported growing on shale (i.e. a sedimentary rock) by Aptroot and Sparrius (2003) in similar set of conditions. In contrast to saxicolous habitat, the foliicolous specimens occur in exposed situations such as the forest canopy and individual trees (Lücking, 2008).

The findings suggests the possibility that B. 
subdiscordans is expanding its habitat and distributional range in Indian subcontinent and also reflects its wider ecological and distributional amplitude in this subcontinent. It also provides a new source of fascination and interest to explorers and lichenologists for further investigation regarding the new records/ species in this subcontinent.

\section{ACK NOW LEDGEMENTS}

The authors would like to thank D.S.T. for providing financial assistance. We are also thankful to Head, Department of Botany, S.S.J. Campus, Almora for providing laboratory facilities.

\section{REFERENCES}

Aptroot, A. (1996). New records of lichens and lichenicolous fungi from British Columbia. Bryologist, 99: 196-198.

Aptroot, A. and Sparrius, L.B. (2003). New microlichens from Taiwan. Fungal Diver sity, 14: 1-50.

Awasthi, D.D. (1975). Lichen flora of Pindari Glacier valley, India. G eophytology, 5: 178-185.

Awasthi, D.D. (1986). Macrolichen taxa of Teloschistaceae from India. Proceedings of the Indian Aca demy of Sciences (Plant Science), 96: 87-97.

Awasthi, D.D. (1991). A key to the macrolichens of India, Nepal and Sri Lanka. Bibliotheca Lichenologica, 40: 1-337.

Awasthi, D.D. and Singh, K.P. (1972). Foliicolous lichens from the Palni and Nilgiri Hills, India. Proceedings of the Indian Academy of Sciences. Section B, 76: 117-132.

Divakar, P.K. and Upreti, D.K. (2005). Parmelioid lichens in India. Bishen Singh Mahendra Pal Singh, Dehradun, India.

Gauniyal, A.K. (2005). Morpho-Taxonomic Studies on Pyrenocarpous Lichens of India. PhD thesis, Dr. R.M.L. Avadh Univeristy, Faizabad.

Giavarini, V. and Sérusiaux, E. (2009). Byssoloma Trevisan. In: C.W. Smith, A. Aptroot, B.J. Coppins, A. Fletcher, O.L. Gilbert, P.W. James, P.A. Wolseley (Eds.) The lichen flora of Great Britain and Ireland. The Natural History Museum and The British Lichen Society, London pp. 239-240.

Hermansson, J. and Thor, G. (2004). Byssoloma subdiscordans and $U$ snea substerilis new to Sweden. G raphis Scripta, 15: 42-44.

Joshi, S. (2010). Diversity of lichens in Pindari and Milam regions of Kumaun Himalaya. PhD thesis, Kumaun University, Nainital.

Joshi, Y. (2008). Morhotaxonomic studies on lichen family Teloschistaceae from India. PhD thesis, Kumaun University, Nainital.

Kantvilas, G. and Jarman, S.J. (1993). The cryptogamic flora of an isolated rainforest fragment in Tasmania. Botanical J ournal of the Linnaean Society, 111:211-228.

Kirk, P.M., Cannon, P.F., Minter, D.W. and Stalpers, J.A. (2008). Ainsworth \& Bisby's Dictionary of the Fungi. 10th edn. CABI Publication, U.K.
Lücking, R. (1992). Foliicolous lichens - a contribution to the knowledge of the lichen flora of Costa Rica, Central America. Beihefte zur Nova H edwigia, 104:1-179.

Lücking, R. (2008). Foliicolous lichenized fungi. Flora Neotropica M onograph, 103:1-866.

Mishra, G.K. (2012). Distribution and ecology of lichens in Kumaun Himalaya, Uttarakhand. PhD thesis, Kumaun University, Nainital

Nayaka, S. (2004). Revisionary studies on lichen genus Lecanora sensu lato in India. PhD thesis, Dr. R.M.L. Avadh Univeristy, Faizabad.

Orange, A., James, P.W., and White, F.J. (2001). Microchemical methods for the identification of lichens. British Lichen Society, London.

Pant, V. (2002). Biodiversity of lichens in botanical hot spots of Pithoragarh district, Uttaranchal. PhD thesis, Kumaun University, Nainital.

Pinokiyo, A. and Singh, K.P. (2004). Foliicolous lichen diversity in India. Phytotaxonomy, 4: 109-121.

Pinokiyo, A., Singh, K.P. and Singh, J.S. (2006). Leaf colonizing lichens: their diversity, ecology and future prospects. Current Science, 90: 509-518.

Rai, H. (2013). Lichens of Uttarakhand: A checklist. https:// sites.google.com/site/himanshuraiindia/checklist-ofuttarakhand. Accessed 20 July 2013.

Santesson, R. (1952). Foliicolous lichens 1. Symbolae botanicae U psalienses, 12:1-590.

Singh, K.P. and Sinha, G.P. (2010). Indian Lichens: An Annotated Checklist, Botanical Survey of India, Kolkata.

Sinha, G.P. and Jagadeesh Ram, T.A.M. (2011). Lichen diversity in Sikkim. In: S. Arrawatia, S. Tambe (Eds.) Biodiversity of Sikkim. Exploring and Conserving a Global Hotspot. Information and Public Relations Department, Government of Sikkim, Gangtok, pp 13-28.

Thor, G., Lücking, R. and Matsumoto, T. (2000). The foliicolous lichens of Japan. Symbolae botanicae U psalienses. 32:1-72.

Upreti, D.K. and Chatterjee, S. (1999). Epiphytic lichens on Quercus and Pinus trees in the three forest stands in Pithoragarh district, Kumaun Himalayas, India. Tropical Ecology, 40: 41-49.

Upreti, D.K. and Chatterjee, S. (2000). Distribution of lichens on Quercus and Pinus trees in Almora district, Kumaon Himalayas. G eophytology, 28: 41-49.

Upreti, D.K., Nayaka, S. and Chatterjee, S. (2010). Lichen diversity of Uttarakhand Himalayas. In: P.L. Uniyal, B.P. Chamola, D.P. Semwal (Eds.) The plant wealth of Uttarakhand. Jagdamba Publishing Co., New Delhi, pp 79195.

Upreti, D.K., Pant, V. and Divakar, P.K. (2001). Distribution of lichens in Askot-Sandev Botanical Hot Spot of Pithoragarh district, Uttar Pradesh. Phytotaxonomy, 1: 40-45.

Wirth, V. (1995). Die Flechten Baden-Württem-bergs. 2nd edn. Ulmer, Stuttgart. 